\title{
Drought can cause phytoplankton growth intensification in Barra Bonita reservoir
}

\author{
Fernanda Watanabe $^{1} \cdot$ Thanan Rodrigues $^{1} \cdot$ Nariane Bernardo $^{1} \cdot$ Enner Alcântara $^{1}$. \\ Nilton Imai ${ }^{1}$
}

Received: 8 July 2016/ Accepted: 11 July 2016/Published online: 20 July 2016

(c) Springer International Publishing Switzerland 2016

\begin{abstract}
In this research, we investigated the possible consequences of the 2012-2014 drought in Southeastern Brazil on growing phytoplankton in a eutrophic reservoir. Weather has direct influence to phytoplankton communities and, consequently, underwater light climate which drives important processes in aquatic systems. Absorption coefficient of phytoplankton pigment $\left(a_{\varphi}\right)$ and chlorophyll$a(\mathrm{Chl}-a)$ concentration were determined in laboratory in order to analyze the interference of phytoplankton biomass over light. In addition, a historical monthly rainfall series in the reservoir was analyzed. Results showed clearly the strong drought effect over the monthly useful volume and flow rate. Both of them play important roles to water column mixing and retention time which increase the nutrients availability in the system and phytoplankton biomass. Chl$a$ concentration and $a_{\mathrm{phy}}$ values were extremely high [maximum Chl- $a$ of $797.8 \mathrm{mg} \mathrm{m}^{-3}$ and $a_{\varphi}(440)$ of almost $6 \mathrm{~m}^{-1}$ in October]. So, more attention should be paid to water quality in long episodes of drought as occurred from 2012 to 2014.
\end{abstract}

Keywords Bio-optical status - Underwater light climate . Chlorophyll- $a \cdot$ Inland waters

Fernanda Watanabe

fernandasyw@gmail.com

1 Department of Cartography, São Paulo State University (UNESP), Rua Roberto Simonsen 305, Presidente Prudente, SP 19060-900, Brazil

\section{Introduction}

Weather conditions such as precipitation, wind and cold front play important roles over the water column mixing (Curtarelli et al. 2014) and, consequently, underwater light climate (Tundisi et al. 2010). The water column mixing and retention time are pointed as the main responsible for phytoplankton species richness in the reservoir (Calijuri et al. 1996; Matsumura-Tundisi and Tundisi 2005; Dellamano-Oliveira et al. 2008). On the other hand, predominance for determined specie is frequently associated with thermal stratification and stability of the water column (Tundisi et al. 2010). Therefore, blooms of cyanobacteria occur in the fall when retention time is longer, while chlorophyta and diatom are more common during the spring and summer when the retention time is shorter (Perry et al. 1990; Lepš et al. 1990).

The Southeastern of Brazil has gone through a long drought period, beginning in 2012 and extending to 2015. According to Getirana (2016) a water loss rate of $-6.1 \mathrm{~cm}$ year ${ }^{-1}$ has been already observed during this period. The low rainfall leaded to a reduction of the useful volume in water bodies and, consequently, a drinking water supply crisis. In reservoirs, low rainfall affects the retention time and quota in the reservoirs due to the flow control. In a highly productive aquatic system the trophic level might still become higher when rainfall decreases and retention time increases. Thus, it was expected that the drought has increased phytoplankton growth in the Barra Bonita reservoir. Therefore, the goal of this research was to investigate if there is relation between the drought and variation of bio-optical measurements associated with primary production collected in 2014. 


\section{Data and methods}

\section{Study area}

The study area was the Barra Bonita hydroelectric reservoir $\left(22^{\circ} 31^{\prime} 10^{\prime \prime} \mathrm{S}\right.$ and $\left.48^{\circ} 32^{\prime} 3^{\prime \prime} \mathrm{W}\right)$ and it lies on middle course of the Tietê River, Brazil (Fig. 1). Operating since 1963, the reservoir is not only used for power generation, but also for navigation, recreation, and fishing. The reservoir has a flooded area of $310 \mathrm{~km}^{2}$ and volume of $3.622 \times 10^{6} \mathrm{~m}^{3}$ (AES Tietê, www.aestiete.com.br). The average depth is $10.2 \mathrm{~m}$, with maximum of $25 \mathrm{~m}$. The land cover is mainly agriculture, highlighting the sugarcane, citrus and coffee crops.

The Barra Bonita hydroelectric reservoir is a storage type system; with quota ranging from 439.5 to $451.5 \mathrm{~m}$. Barra Bonita is located in a transitional zone between tropical and subtropical climate, characterized by a dry season (May to October) and a wet season (November to April). The flow rate ranges according to the seasons, from $200 \mathrm{~m}^{3} \mathrm{~s}^{-1}$ in the austral winter (dry season) to $1500 \mathrm{~m}^{3}$ $\mathrm{s}^{-1}$ in the austral summer (wet season). The retention time also varies between 30 days in the dry season and 180 days in the wet season (Calijuri et al. 1996; Matsumura-Tundisi and Tundisi 2005).

The Barra Bonita reservoir is the first of six reservoirs in the cascade system of Tietê River and, therefore, it receives a high wastewater discharge coming from São Paulo metropolitan area and Piracicaba city, characterized as a populous and industrialized region. Due to eutrophication and high retention time there is an intense phytoplankton biomass growth (Calijuri et al. 2002; Dellamano-Oliveira et al. 2008; Watanabe et al. 2015). According to Barbosa et al. (1999), the Barra Bonita reservoir is classified as a polymictic ecosystem influenced by wind, fluctuations in rainfall, intrusion of water from tributaries, low retention time in austral summer and density currents caused by the two tributaries (Piracicaba and Tietê rivers), leading the horizontal and vertical mixing within the aquatic system.

\section{Field survey}

The samples used were collected in two field surveys carried out in May 5-9 and October 13-16, 2014. Approximately 51 of water were collected in each sampling point (see location in Fig. 1) to measure: the absorption coefficients (phytoplankton pigment, nonalgal particles and colored dissolved organic matter), and concentration (chlorophyll- $a$ and suspended solids).

\section{Concentration of photo-active components}

To determine chlorophyll- $a$ (Chl- $a$ ) concentration approximately $250 \mathrm{ml}$ of water collected in each sampling point were filtered through Whatman GF/F glass fiber filter, with $47 \mathrm{~mm}$ diameter and $0.7 \mu \mathrm{m}$ pore size (GE Healthcare, Little Chalfont, UK) under vacuum pressure. The filters with retained material were stored and kept frozen and protected from the light until analysis. Spectrophotometry
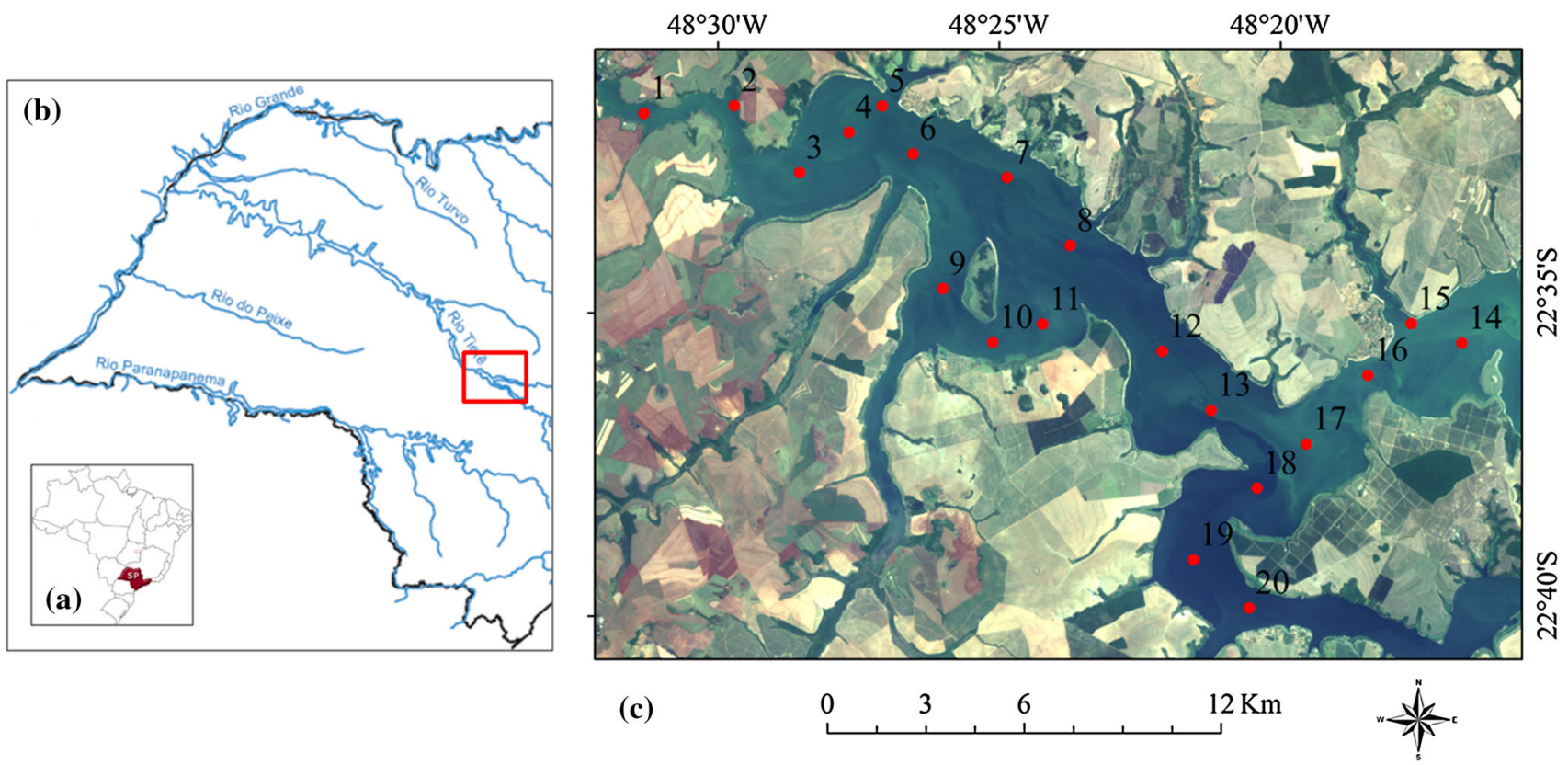

Fig. 1 Location of the study area in a Brazil and São Paulo State (in red) and b reservoir cascade in the Tietê River, São Paulo State. $\mathbf{c}$ Barra Bonita hydroelectric reservoir and sampling stations 
was the method chosen for Chl- $a$ determination with pigment extraction using $90 \%$ acetone (Golterman 1975).

Total suspended solids (TSS) concentration and its organic and inorganic fractions (OSS and ISS, respectively) were determined using methodology proposed by APHA (1998). In addition, $250 \mathrm{ml}$ of sample water were filtered using Whatman GF/F glass fiber glass $(47 \mathrm{~mm}$ diameter and $0.7 \mu \mathrm{m}$ pore size) previously burned. As with Chl- $a$, the filters were kept frozen and in the dark until analysis. Firstly, the filters were dried in an oven at about $110^{\circ} \mathrm{C}$ for $12 \mathrm{~h}$ to determine TSS and to determine the ISS, the filters were burned in a furnace muffle at approximately $500{ }^{\circ} \mathrm{C}$ for $30 \mathrm{~min}$. OSS was determined subtracting ISS from TSS.

\section{Absorption coefficient of phytoplankton pigment}

The Transmittance-Reflectance (T-R) method was used to determine $a_{\varphi}(\lambda)$ and nonalgal particle absorption coefficient, $a_{\mathrm{NAP}}(\lambda)$ (Tassan and Ferrari 1995, 1998, 2002). Water samples collected in each sampling point were filtered using Whatman GF/F glass fiber filter $(47 \mathrm{~mm}$ diameter and $0.7 \mu \mathrm{m}$ pore size) (GE Healthcare, Little Chalfont, UK). The retained material onto filter were stored in sterile jars and kept frozen and in the dark until analysis. The reflectance and transmittance measurements were read using a UV-2600 model, UV-Vis spectrophotometer (Shimadzu, Kyoto, Japan) in dual-beam mode and an integration sphere.

The measurements were acquired in a range from 280 to $800 \mathrm{~nm}$ and spectral resolution of $1 \mathrm{~nm}$. A Whatman GF/F filter was used to correct the multiple scattering effects caused by the filter itself (Cleveland and Weidmann 1993). The transmittance and reflectance measurements were empirically converted from the optical density of the particle sample $\left(O D_{\mathrm{s}}\right)$ into optical density of the suspended particles $\left(O S_{\text {sus }}\right)$. To determine the optical density only of the NAP, the pigments were removed by chemical oxidation using $10 \%$ sodium hypochlorite solution (Mitchell et al. 2000) and measured transmittance and reflectance again. The total particles $a(\lambda), a_{\mathrm{p}}$, and $a_{\mathrm{NAP}}$ were calculated using Eq. 1.

$a_{p, N A P}(\lambda)=\frac{2.3 O D_{s u s, N A P}(\lambda)}{X \cdot C}$,

where $O D_{\text {sus }}$ is the optical density of particles on the filter; $X$ is the ratio of the filtered volume to the filter clearance area $(\mathrm{m})$; and $C$ is the particle concentration (mass $\mathrm{m}^{-3}$ ). The $a_{\varphi}$ was obtained by subtracting the $a_{N A P}$ from the $a_{p}$ (Eq. 2)

$a_{\phi}(\lambda)=a_{p}(\lambda)-a_{N A P}(\lambda)$.

\section{Results}

\section{Concentration of the photo-active components}

Chl- $a$ concentrations were very high in both field surveys, specially, in October when reached extreme value of $797.8 \mathrm{mg} \mathrm{m}^{-3}$. In May, Chl- $a$ ranged from 17.7 to $279.9 \mathrm{mg} \mathrm{m}^{-3}$, with an average of $120.4 \mathrm{mg} \mathrm{m}^{-3}$, while, in October, the variation of this variable was from 263.2 to $797.8 \mathrm{mg} \mathrm{m}^{-3}$, with an average of $428.7 \mathrm{mg} \mathrm{m}^{-3}$. It is noticed that the Chl- $a$ average was thirdfolder in October than May. Figure 2a showed the difference of Chl- $a$ concentration measured in both field surveys. In October, the phytoplankton biomass was so high that all the sampling points would be classified as hypereutrophic.

Additionally, TSS concentration was remarkably higher in October than May. In May, the range was from 3.6 to $16.3 \mathrm{~g} \mathrm{~m}^{-3}$, with an average of $7.2 \mathrm{~g} \mathrm{~m}^{-3}$ and, in October, the variation was from 10.8 to $44 \mathrm{~g} \mathrm{~m}^{-3}$, with an average of $22 \mathrm{~g} \mathrm{~m}^{-3}$ (Fig. 2b). Analyzing the inorganic and organic fractions, the OSS contributed with more than $80 \%$ in both field surveys (average of 83 and $87 \%$ for May and October, respectively), as reported by Rodrigues et al. (2016). The predominance of the organic fraction is an indicative that TSS is mainly composed for phytoplankton biomass. The high Chl$a$ and TSS concentration affected directly turbidity and Secchi transparency measurements (Fig. 2c, d). As expected, the turbidity was on average higher in October (18.6 NTU) than in May (5.2 NTU), meanwhile, on the opposite, Secchi transparency was considerably lower in October. These results showed a light decay in the water column from May (autumn) to October (spring).

\section{Pigment phytoplankton absorption coefficient}

Figure $3 \mathrm{a}, \mathrm{b}$ showed the $a_{\varphi}(\lambda)$ spectra acquired in May and October 2014, respectively. As expected, there clearly is a higher absorption in the blue region, highlighting two absorption peaks at 412 and $440 \mathrm{~nm}$, and in the red region. It is notable that $a_{\varphi}(\lambda)$ was lower in May, explained by the lower Chl- $a$ concentrations observed in the first field survey. In May, $a_{\varphi}(440)$ did not exceed $3 \mathrm{~m}^{-1}$, while in October, $a_{\varphi}(440)$ almost reached $6 \mathrm{~m}^{-1}$. Sampling point 3 (see green line in Fig. 3b) exhibited the greatest values of $a_{\varphi}$ spectrum. Sampling point 3 is located before narrowing the channel close to the dam where the water flow is lower. This point matched with that of highest value of Chl- $a\left(797.8 \mathrm{mg} \mathrm{m}^{-3}\right)$.

On the other hand, in May the sampling point 4 (see lower purple curve in Fig. 3) showed the lowest $a_{\varphi}(\lambda)$ spectrum, with Chl- $a$ concentration of $26.2 \mathrm{mg} \mathrm{m}^{-3}$, the 
Fig. 2 Box-plot of a Chl$a$ concentration, b TSS concentration, $\mathbf{c}$ turbidity and d Secchi disk collected in May and October 2014
Fig. 3 Pigment phytoplankton absorption coefficient $\left(a_{\varphi}\right)$ spectra measured in a May and b October 2014
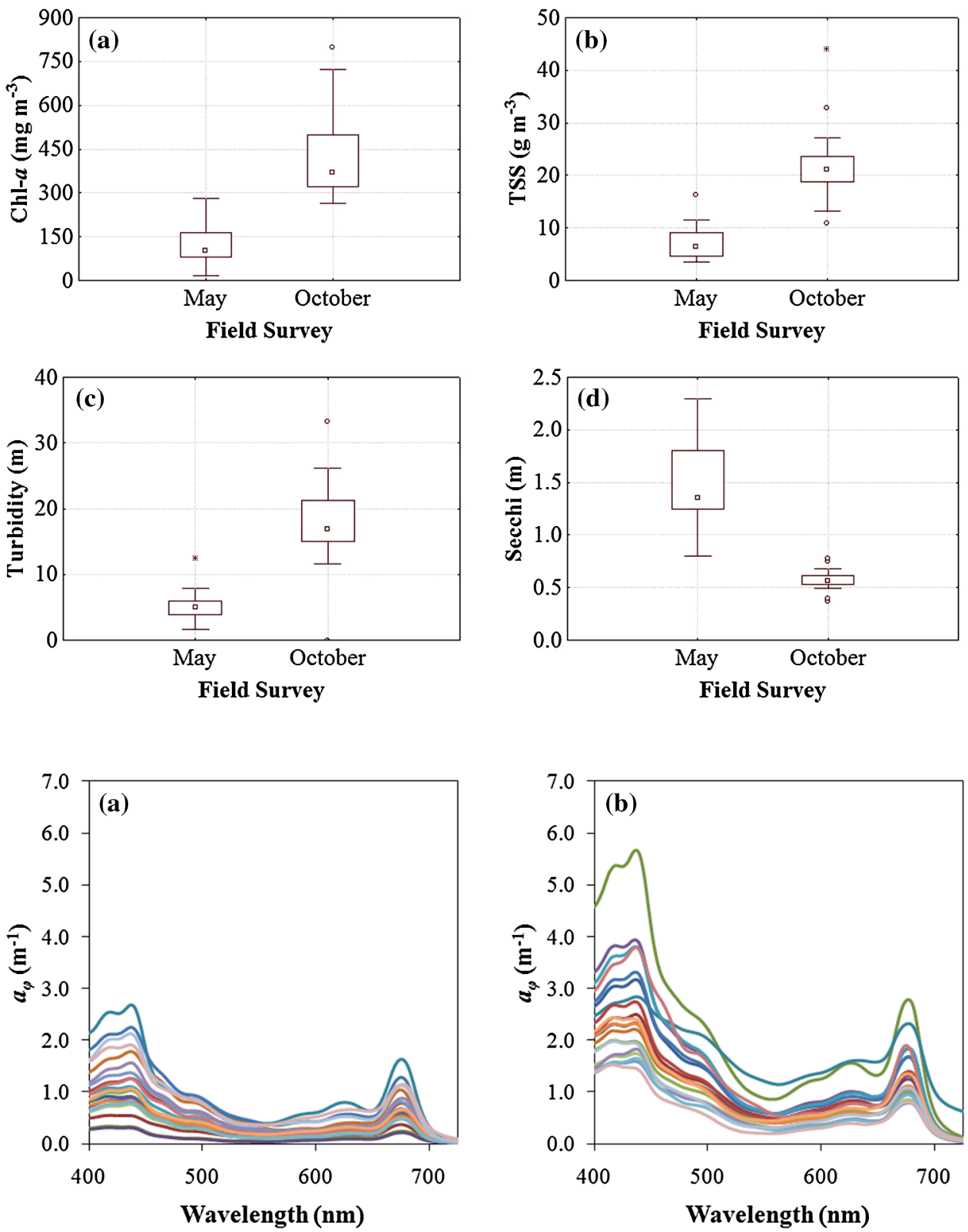

second lowest Chl- $a$ value reported in both field surveys. Unexpectedly, the sampling point 3 also exhibited the lowest Chl- $a$ concentration of $17.8 \mathrm{mg} \mathrm{m}^{-3}$, in May. The occurrence of extreme values in a same sampling point shows a high bio-optical variability which, in this case, it might be associated not only with season, but also with the drought event. Studies about bio-optical status in the Barra Bonita reservoir pointed a high variability of its inherent optical properties (Alcântara et al. 2016; Rodrigues et al. 2016). According to Soares et al. (2012), eutrophication and retention time are responsible for the longitudinal heterogeneity in reservoirs, because they create transitional zone due to the increase in sedimentation.

\section{Discussion}

Figure 4 shows the monthly rainfall between 2012 and 2015 as well as the average monthly rainfall for years from 2009 to 2015 acquired in the Barra Bonita meteorological station monitored by National Institute of Meorology (INMET). As expected, the Barra Bonita region exhibits drier winters and wetter summers. However, São Paulo State faced a rigorous drought from 2012 to 2015 as shown in Fig. 4. The driest year was 2012, with an extremely low annual precipitation of $874 \mathrm{~mm}$. The drought has leaded to a serious water crisis, rationing the drinking water supply in some cities of the São Paulo State from 2014 to 2015. Additionally, the year 2014 exhibited a rainfall below 
Fig. 4 Monthly rainfall for years of 2012, 2013 and 2014 and mean for last 7 years (2009-2015) (INMET, http:// www.inmet.gov.br)

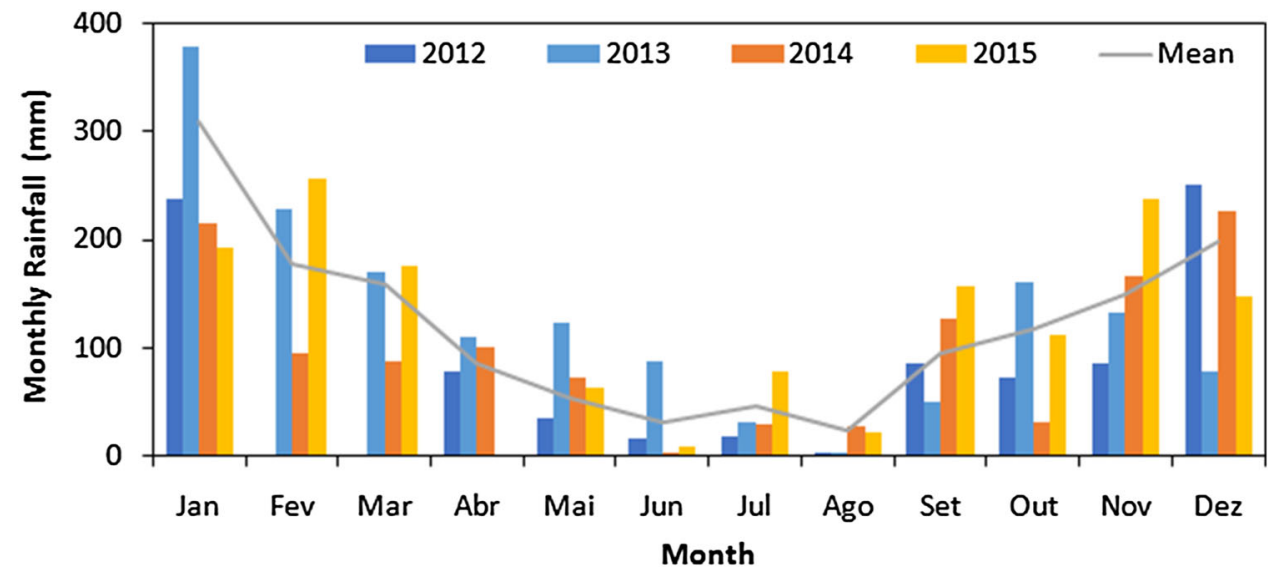

Fig. 5 Monthly flow rate for years of 2012, 2013 and 2014 and mean for last 6 years (2009-2014) (ONS, http://www. ons.org.br)

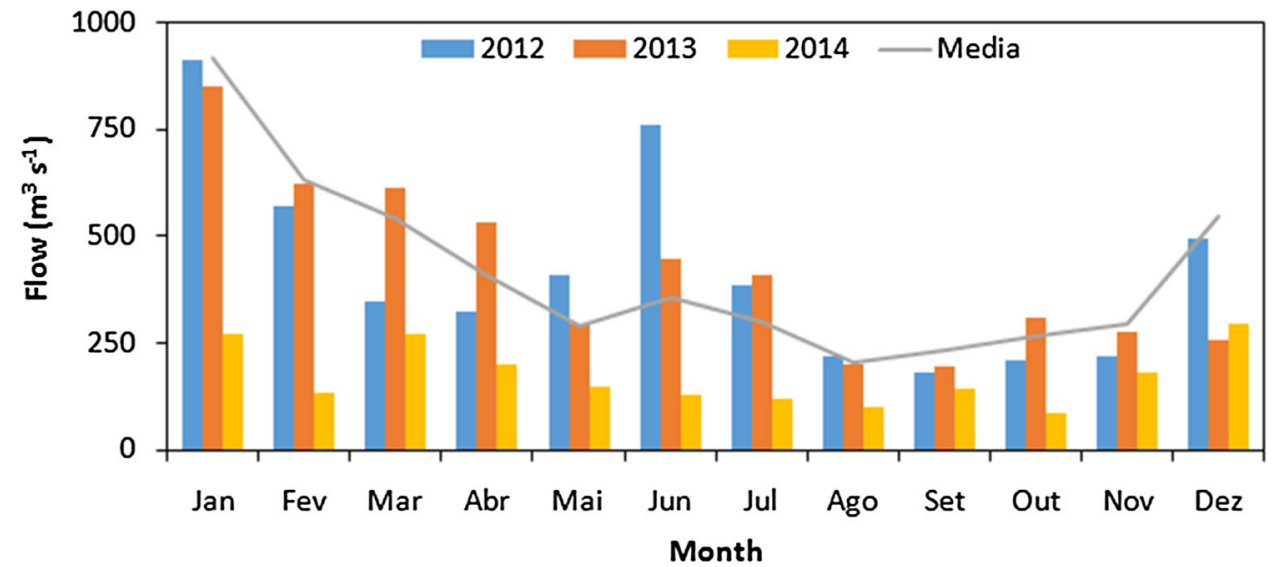

average with an annual precipitation of $1174 \mathrm{~mm}$, while the average for 2009 to 2015 (last 7 years) was of $1447 \mathrm{~mm}$.

Prolonged low rainfall affected immensely the monthly flow rate through the dam (Fig. 5). It is clearly the lower flow rate in Barra Bonita during all the 2014 year, not exceeding $300 \mathrm{~m}^{3} \mathrm{~s}^{-1}$ even in the summer. However, decreasing the flow had already been occurring since 2012 when starts the extreme drought event.

Besides rainfall, in reservoirs the low flow is associated with the control of the water level which might be verified in Fig. 6. Although the long dry period has decreased in the useful volume in the Barra Bonita reservoir, the reduction was not proportional to monthly rainfall and flow. Despite this, the reflex of decreasing the volume over quota prevented the use of the Paraná-Tietê waterway, important flow route of commodities in Brazil. In 2014 monthly useful volume was below average during all the year, while in 2012, the driest year, the useful volume started to decrease from winter (July).

In addition, an important consequence of the quota control in reservoirs is the elevation of the retention time which has been pointed as one of the factors of algal blooms, specially cyanobacteria, in the Barra Bonita reservoir (Calijuri et al. 2002). Several studies carried out in the Barra Bonita reservoir have already been highlighting its eutrophic status and intense phytoplankton growth (Calijuri et al. 1996, 2002; Barbosa et al. 1999; Matsumura-Tundisi and Tundisi 2005; Dellamano-Oliveira et al. 2008). However, none of them reported so high Chl- $a$ concentrations (maximum value of $438 \mathrm{mg} \mathrm{m}^{-3}$ ) as those obtained in 2014. Even in eutrophic aquatic ecosytems, Chl- $a$ concentrations values as high as $797.8 \mathrm{mg} \mathrm{m}^{-3}$ seldom are found. Rangel et al. (2012) obtained a median Chl- $a$ values of $1331 \mathrm{mg} \mathrm{m}^{-3}$ in the Funil reservoir, in Paraíba do Sul River (Brazil). As the Barra Bonita reservoir, Funil also receives a high sewage discharge.

\section{Conclusion}

Considering Chl- $a$ concentration historical in the Barra Bonita reservoir and meteorological conditions in Southeastern region, we concluded that the long drought period from 2012 to 2014 was the main responsible for the extreme phytoplankton growth reported in 2014. In Barra 
Fig. 6 Monthly useful volume for years of 2012, 2013 and 2014 and mean for last 7 years (2009-2015) (ONS, http://www. ons.org.br)

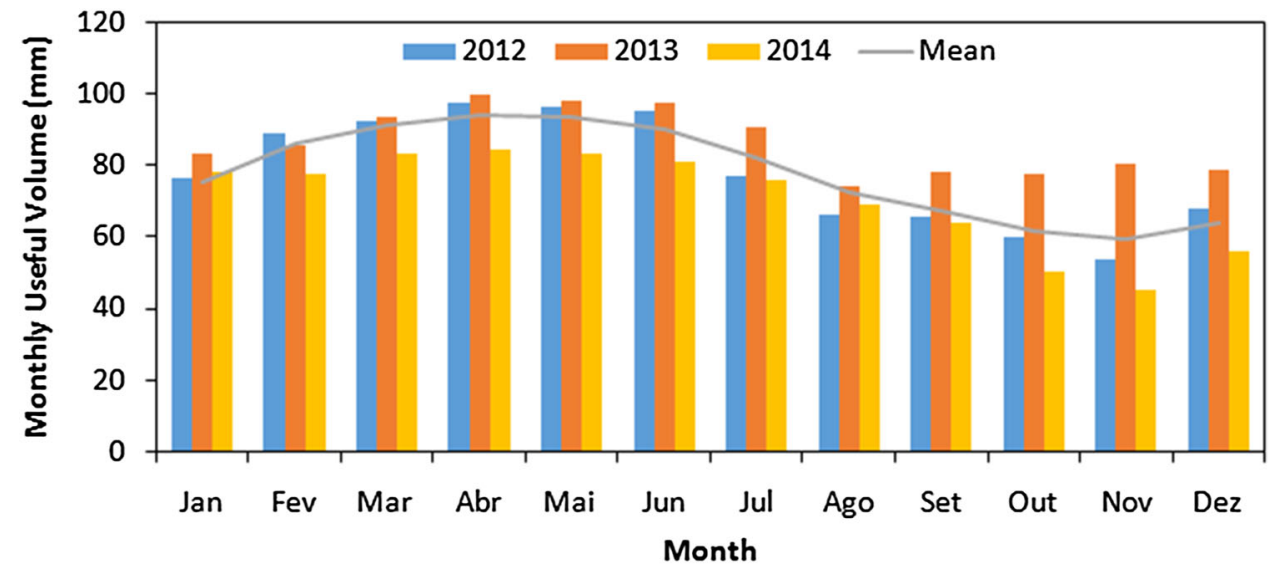

Bonita reservoir, low rainfall leaded to an events chain such as control of water quota, flow reduction and, consequently, increase of the retention time which creates conditions to developing of phytoplankton. Also, it might conclude that the reservoir water quality is hampered during episodes of drought, increasing its tropical level.

Acknowledgments The authors thank FAPESP (Process N. 2012/19821-1 and 2013/09045-7), CNPq (Processes N. 472131/20125 and 482605/2013-8), Science without Borders/CNPq/MCTI (Process N. 400881/2013-6) and PPGCC/UNESP for financial support and CAPES for scholarships. The authors also thank Professor Edivaldo D. Velini and the staff from FCA/UNESP for allowing the use of the Laboratory of Weed Science.

\section{References}

Alcântara E, Rodrigues T, Watanabe F, Bernardo N (2016) An investigation into the particle volume scattering function variability in a cascading reservoir system. Model Earth Syst Environ 2:89. doi:10.1007/s40808-016-0149-z

APHA (American Public Health Association), AWWA (American Water Works Association), WEF (Water Environmental Federation) (1998) Standard methods for the examination of water and wastewater, 20th edn. APHA, AWWA, WEF, Washington, DC, USA

Barbosa FAR, Padisák J, Espíndola ELG, Borics G, Rocha O (1999) The cascading reservoir continuum concept (CRCC) and its application to the river Tietê-basin, São Paulo State, Brazil. In: Tundisi JG, Straśkraba M (eds) Theoretical reservoir ecology and its applications. International Institute of Ecology, São Carlos, Brazil, pp 425-437

Calijuri MC, Dos Santos ACA, Jati S (1996) Short-term changes in the Barra Bonita reservoir (São Paulo, Brazil): emphasis on the phytoplankton communities. Hydrobiologia 330:163-175

Calijuri MC, Dos Santos ACA, Jati S (2002) Temporal changes in the phytoplankton community structure in a tropical and eutrophic reservoir (Barra Bonita, SP, Brazil). J Phytoplankton Res 24(7):617-634

Cleveland JS, Weidmann AD (1993) Quantifying absorption by aquatic particles: a multiple scattering correction for glass-fiber filters. Limnol Oceanogr 38(6):1321-1327
Curtarelli MP, Alcântara EH, Rennó CD, Stech JL (2014) Physical changes within a large tropical hydroelectric reservoir induced by wintertime cold front activity. Hydrol Earth Syst Sci 18:3079-3093. doi:10.5194/hess-18-3079-2014

Dellamano-Oliveira MJ, Vieira AAH, Rocha O, Colombo V, Sant'Anna CL (2008) Phytoplankton taxonomic composition and temporal changes in a tropical reservoir. Fundam Appl Limnol 171(1):27-38

Getirana A (2016) Extreme water deficit in Brazil detected from space. J Hydrometeorol 17:591-599

Golterman H (1975) Developments in water science 2 Physiological limnology: an approach to the physiology of lake ecosystems. Elsevier, Amsterdam

Lepš J, Straškraba M, Desortová B, Procházková L (1990) Annual cycles of plankton species composition and physical chemical conditions in Slapy reservoir detected by multivariate statistics. Arch Hydrobiol Beih Ergeb Limnol 33:933-945

Matsumura-Tundisi T, Tundisi JG (2005) Plankton richness in a eutrophic reservoir (Barra Bonita reservoir, SP, Brazil). Hydrobiologia 542:367-378

Perry SA, Perry WB, Simmons GM Jr (1990) Bacterioplankton and phytoplankton populations in a rapidly-flushed eutrophic reservoir. Internationale Revue der gesamten Hydrobiologie und Hydrographie 75(1):27-44

Rangel LM, Silva LHS, Rosa P, Roland F, Huszar VLM (2012) Phytoplankton biomass is mainly controlled by hydrology and phosphorus concentrations in tropical hydroelectric reservoirs. Hydrobiologia 693:13-28

Rodrigues T, Alcântara E, Watanabe F, Bernardo N, Rotta L, Imai N (2016) Spatial and temporal variations of the inherent optical properties in a tropical cascading reservoir system. Model Earth Syst Environ 2:86. doi:10.1007/s40808-016-0144-4

Soares MCS, Marinho MM, Azevedo SMOF, Branco CWC, Huszar VLM (2012) Eutrophication and retention time affecting spatial heterogeneity in a tropical reservoir. Limnologica 42:197-203

Tassan S, Ferrari GM (1995) An alternative approach to absorption measurements of aquatic particles retained on filters. Limnol Oceanogr 40(8): 1358-1368

Tassan S, Ferrari GM (1998) Measurements of light absorption by aquatic particles retained on filters: determination of the pathlength amplification by the 'transmittance-reflectance' method. J Plankton Res 20(9):1699-1709

Tassan S, Ferrari GM (2002) A sensitivity analysis of the 'transmittance-reflectance' method for measuring light absorption by aquatic particles. J Plankton Res 24(8):757-774 
Tundisi JG, Matsumura-Tundisi T, Pereira KC, Luzia AP, Passerini MD, Chiba WAC, Morais MA, Sebastien NY (2010) Cold fronts and reservoir limnology: an integrated approach towards the ecological dynamics of freshwater ecosystems. Braz J Biol 70(3):815-824
Watanabe FSY, Alcântara E, Rodrigues TWP, Imai NN, Barbosa CCF, Rotta LHS (2015) Estimation of chlorophyll-a concentration and the trophic state of the Barra Bonita hydroelectric reservoir using OLI/Landsat-8 images. Int J Environ Res Public Health 12:10391-10471 